\title{
Growth and regrowth of tough lovegrass (Eragrostis plana Nees)
}

\author{
Simone Meredith Scheffer-Basso ${ }^{1}$, Adriana Favaretto ${ }^{2}$, Vanderleia Felini ${ }^{3}$, Kalinca Cecchin ${ }^{3}$ \\ 1 Universidade de Passo Fundo (UPF). Scholar from CNPq. \\ ${ }^{2}$ Curso de Ciências Biológicas da Universidade de Passo Fundo. Undergraduate research scholar from UPF. \\ ${ }^{3}$ Curso de Ciências Biológicas da Universidade de Passo Fundo. Undergraduate research scholar from CNPq.
}

\begin{abstract}
This study evaluated the morphological development of two populations of tough lovegrass during 120 days of continuous growth (Experiment I), and the regrowth of one population under the combination of cutting height (5 $\mathrm{cm}$ and $10 \mathrm{~cm}$ ) and phenological stage at the first cutting (vegetative and beginning of flowering; Experiment II). In Experiment I, plants were harvested at 30, 60, 90 and 120 days of growth; in Experiment II, three cuttings were carried out at every 30 days, and the plants were harvested four weeks after the previous one. In Experiment I, the populations did not differ for morphological development, showing a linear increase in height and tiller number, and a quadratic trend for root and shoot dry matter (DM). At 120 days of growth, plants presented 10 basal tillers and 80 leaves, strongly compressed at the base and no sign of senescence. In Experiment II, there was no significant cutting height $\times$ phenological stage interaction, but cuttings at $5 \mathrm{~cm}$ reduced plant size and yield. Cuttings started at the vegetative stage decreased the root (3.06 g DM/plant) and stubble dry matter (1.17 $\mathrm{g}$ DM/plant), compared with $6.84 \mathrm{~g}$ and $3.99 \mathrm{~g} \mathrm{DM} /$ plant, respectively, with cuttings started at the flowering stage. Tough lovegrass shows basal architecture, basal bud renovation, leaves densely compressed in the tiller base, high belowground allocation, and elongation of internodes only in reproductive stage. Mechanical control is an alternative method to minimize its growth, especially if it is carried out early in the growing season and at low cutting height.
\end{abstract}

Key Words: cutting height, phenological stage, root, stubble

\section{Introduction}

Tough lovegrass (Eragrostis plana Nees) is a SouthAfrican grass, which was accidently introduced in the 1950s in the south of Brazil, considered the most aggressive weed and the most difficult to be controlled in the fields, responsible for infesting one million hectares in Rio Grande do Sul (Medeiros \& Focht, 2007). It is a perennial, warmer and caespitose grass, having the shoot and root system resistant to mechanical traction (Kissmann, 1997). These characteristics, together with the high seed production, which are persistent and numerous, allow its high propagation.

The invasion of this grass is due to its easy dissemination, low nutritional quality, poor acceptance by the animals, high competitiveness and drought resistance (Nascimento \& Hall, 1978; Abichequer et al., 2009). Alfaya et al. (2002) recorded $6.9 \%$ of crude protein in hay of this species, which is low for the minimal amount required for ruminants (7\%). Tough lovegrass represents a great problem to the farmers, as the animal rejection favors the accumulation of great matter quantity (Medeiros \& Focht, 2007). Its occurrence is common in overgrazed and excessively burned pasture (Brink, 2006), which amplifies its establishment and persistence, reducing the presence of species with better nutritive value. The species also presents active allelopathic mechanisms, inhibiting the germination and seedling growth of others species (Coelho, 1986; Favaretto et al., 2011).

Medeiros \& Focht (2007) suggested the possibility of restoring the natural pastures contaminated by this grass by manipulating grazing pressure of less selective herbivores, rotational grazing, deferment, protein/energetic supplementation, and strategic mowing to avoid seed production.

The objective of this study was to analyze the growth of two tough lovegrass populations and the regrowth of one population under cutting regimes.

\section{Material and Methods}

Two experiments were carried out, between October 2009 and March 2010, to evaluate the morphological development of two populations (Experiment I), and the regrowth of one population of tough lovegrass submitted to cuttings (Experiment II). Both trials were conducted in greenhouse, with automatic irrigation by aspersion. The monthly mean temperatures were: October $/ 09=24.5^{\circ} \mathrm{C}$, November $/ 10=28.6^{\circ} \mathrm{C}$, December $/ 09=28.7^{\circ} \mathrm{C}$, January $/ 10=$ 
$28.7^{\circ} \mathrm{C}$, February $/ 10=29.4^{\circ} \mathrm{C}$ and March $/ 10=27.6^{\circ} \mathrm{C}$. The plants were cultivated in pots containing 5 kg of Ferticel ${ }^{\circledR}$ substrate, with the following attributes: $\mathrm{pH}$ : 7.1; dry matter content: 49.5\%; $\mathrm{N}=5.3 \mathrm{~g} / \mathrm{kg} ; \mathrm{P}=2.2 \mathrm{~g} / \mathrm{kg} ; \mathrm{K}=3.3 \mathrm{~g} / \mathrm{kg}$; $\mathrm{Ca}=4.6 \mathrm{~g} / \mathrm{kg}$; and $\mathrm{Mg}=3.8 \mathrm{~g} / \mathrm{kg}$.

In Experiment I, the populations were selected considering caryopsis weight (population $1=14 \mathrm{mg} / 100$ caryopsis; population $2=17 \mathrm{mg} / 100$ caryopsis). The plants were harvested at 30, 60, 90 and 120 days of growth (age), in completely randomized design, with five replications, which totalized forty experimental units ( 2 populations $\times 4$ ages $\times$ 5 replications). Ten seeds were sown, and the seedlings were thinned to leave three plants in each pot. At each harvest, plants were evaluated for height, number of tillers and leaves, shoot and root dry matter accumulation. The plant material was dried in forced ventilation oven at $60{ }^{\circ} \mathrm{C}$ for $72 \mathrm{~h}$ and weighed. The average of the three plants per pot was considered to statistical analysis and presentation of results.

In Experiment II, plants with four tillers were obtained from clump division of adult plants present on the edge of the field crop. After planting, a uniform cutting at $10 \mathrm{~cm}$ from the base of the plant was performed. The treatments were constituted of a combination of cutting height $(5$ and $10 \mathrm{~cm})$ and phenological stage at the first cutting (vegetative and beginning of flowering). The design was completely randomized, with six replications, totaling 24 experimental units. There were three cuttings, at 30, 60 and 90 days after the seedlings transplant to the vegetative treatment, and at 90, 120 and 150 and 180 days for beginning of flowering treatment.

Immediately before the cuttings, plants were evaluated for height, length of the longest leaf, number of tillers below and above of the cutting height, regardless of whether they had the apical meristem removed or not, and number of total tillers. The final evaluation was carried out when the plants were removed from the pots, and in addition to the variables described above, the diameter of the crown (the base of stems where roots are attached) was measured. The plants were separated in tillers + leaves above the stubble ( 5 or $10 \mathrm{~cm}$ ), roots, dead and live (green) stubble and these fractions were oven-dried $\left(60^{\circ} \mathrm{C}, 72 \mathrm{~h}\right)$ and weighed. Root:shoot and live stubble:live shoot ratios were calculated.

In Experiment I, the data were submitted to Anova, and also to regression analysis to quantify the relationship between dependent variables and days of growth (independent variable). The data obtained in all replications, rather than the average of the treatments, were plotted in dispersion graphics, with the subsequent trend line and equation. In Experiment II, the results obtained in the final harvest were submitted to Anova and performed by bifactorial model (cutting height $\times$ phenological stage). The averages were compared by Tukey test at $5 \%$ of probability level. The data were submitted to repeated Anova measures to evaluate the results obtained in each cutting. The statistical procedures were performed using Sisvar software (Ferreira, 2000), with data transformed into square root $\mathrm{Y}+0.5-\mathrm{SQRT}(\mathrm{Y}+0.5)$.

\section{Results and Discussion}

The overall patterns of cumulative dry matter, leaf and tiller number were similar for both populations $(\mathrm{P}>0.05)$. At 120 days of growth the plants were at the end of the juvenile stage, showing elongation of internodes. The tillering and the height of the plants increased linearly, and at 120 days the plants presented 10 tillers and $30 \mathrm{~cm}$ of height (Figure 1).
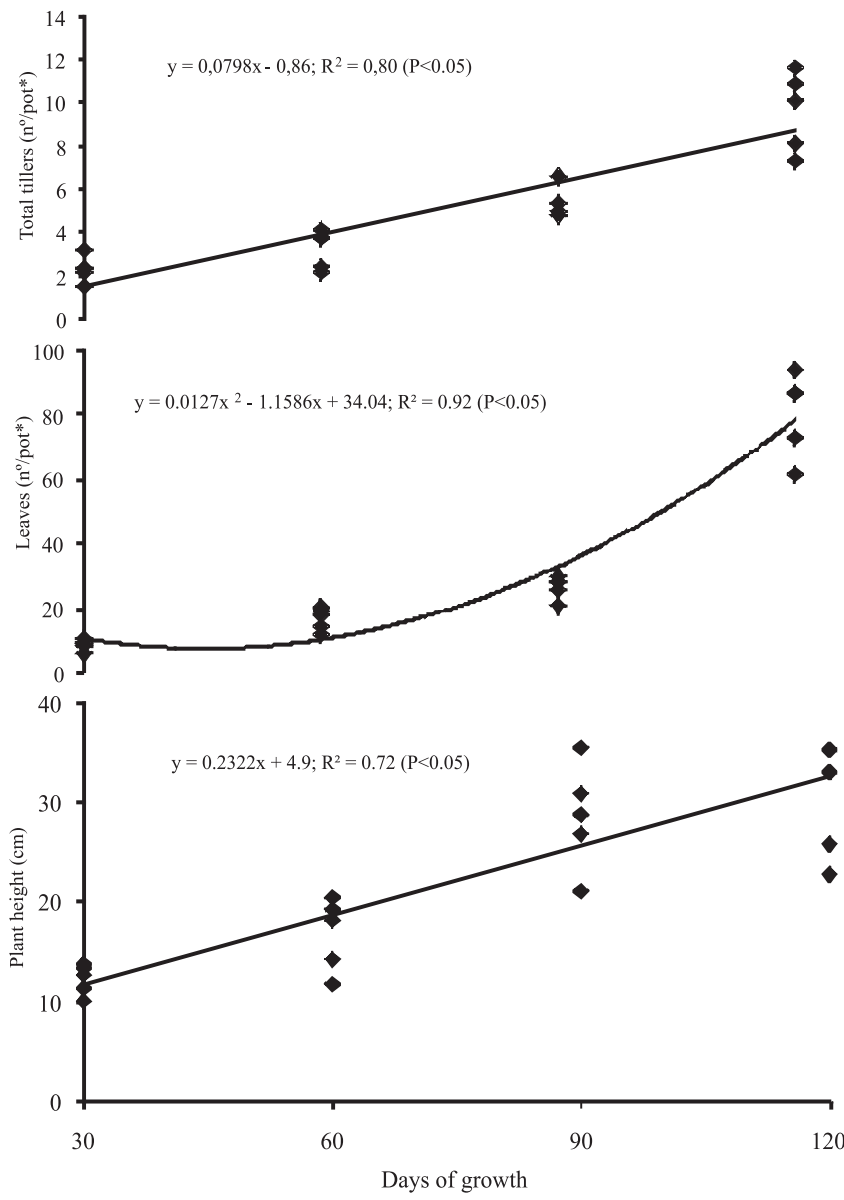

Figure 1 - Dynamics of tillers, leaves and height of tough lovegrass as function of days of growth, on the average of two populations. *Average of three plants. Coefficient of variation $(\%)$ : tillers $=16.9$; leaves $=17.8 \%$; height $=$ $11.9 \%$. 
Adult plants of tough lovegrass can reach from 90 to $100 \mathrm{~cm}$ (Cope, 1998; Brink, 2006), in natural conditions and in interrupt growth. In this study the plants presented the first inflorescences at 90 days of growth, when they suffered the cutting, which explains the divergence between the results. The leaf number increased quadratically, with higher increment from the $60^{\text {th }}$ day, reaching 80 leaves at 120 days of growth. This resulted in 8 leaves per tiller, which is elevated if compared with other perennial grasses from natural pastures. Baréa et al. (2006) observed in Paspalum paniculatum L., a native rhizomatous grass, 55 leaves distributed in 14 tillers, at 143 days of growth, resulting in 5 leaves per tiller. However, tough lovegrass was similar to cv. Tifton 85 (Cynodon spp.), whose leaf production per tiller was 9 to 10 at 28 days after the plant cutting (Oliveira et al., 2000).

The leaves of tough lovegrass were characterized by the strong compression at the culm base, which was also highlighted by Welker \& Longhi-Wagner (2007). The tillers were initiated from the crown buds, which is the major determinant of basal architecture (Descoings, 1975), and there was no axillary tillers, rhizomes and stolons, in agreement with Cope (1998). The strong leaf compression and the basal architecture are adaptations which, possibly, optimize its persistency and resistance to mowing/grazing because the apical buds remain well-protected by the leaf sheath. The crown origin of tillers shows that the longevity of the tough lovegrass is basal bud-dependent. This is common in native pasture grasses of the south of Brazil (Baréa et al., 2006; Scheffer-Basso \& Gallo, 2008). During the 120 days of continuous growth there was no foliar senescence, which reveals the high leaf duration, and must be a factor that contributes to the strong persistence of the tough lovegrass.

The shoot and root yield increased quadratically (Figure 2), with $12 \mathrm{~g}$ and $4 \mathrm{~g} \mathrm{DM}$ /plant at 120 days, respectively. The partition of fotoassimilates was relatively stable, with $60-70 \%$ of DM allocated to shoot and the remaining to root (Figure 3). The allocation to belowground was superior to that registered by Baréa et al. (2006) for P. paniculatum at 176 days of growth (29\%). The root allocation (30-40\%) was high, considering the fertile substrate where the plants were cultivated, because this condition usually promotes a low root:shoot ratio. The high competitiveness of tough lovegrass in relation to native species can be related to long and deep root systems, which allow high absorption of nutrients and access to the soil humidity (Abichequer et al., 2009).

The morphological traits and growth dynamic of tough lovegrass, as bunch growth form, high proximity of tillers, longevity of leaf and root:shoot ratio, as observed in this study, are typical of low-N level grasses (Craine, 2003). The low crude protein (6.9\%) was registered by Alfaya et al. (2002) in hay of this grass, indicating $1.1 \%$ of $\mathrm{N}$ content. According to Medeiros \& Focht (2007), these characteristics can explain, in part, the adaptive advantage of tough lovegrass to colonize openings in the grassland vegetation in degraded soils, with high abundance of species with high N-level, like $P$. notatum Flüggé.

In Experiment II, there was no effect of cutting height $\times$ phenological stage interaction on the morphological attributes, in the final harvest, with simple effects of factors. The plants cutting from the beginning of flowering presented higher number of tillers, crown size, root and stubble DM production and root:shoot ratio (Table 1). The plants whose first cutting was carried out in the vegetative stage showed superiority only in the segment harvested above the stubble (5 or $10 \mathrm{~cm}$ ), which was a consequence of smaller number of

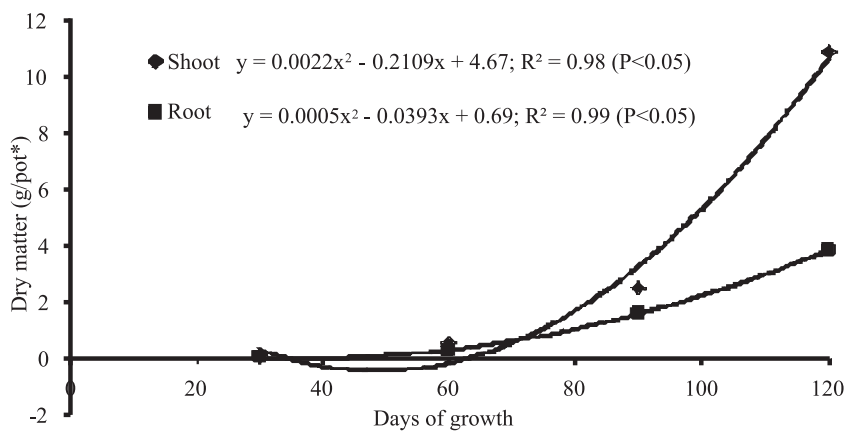

Figure 2 - Shoot and root dry matter dynamics of tough lovegrass as function of days of growth on the average of two populations. *Average of three plants. Coefficient of variation $(\%)$ : shoot $=27.6$; roots $=26.3$.

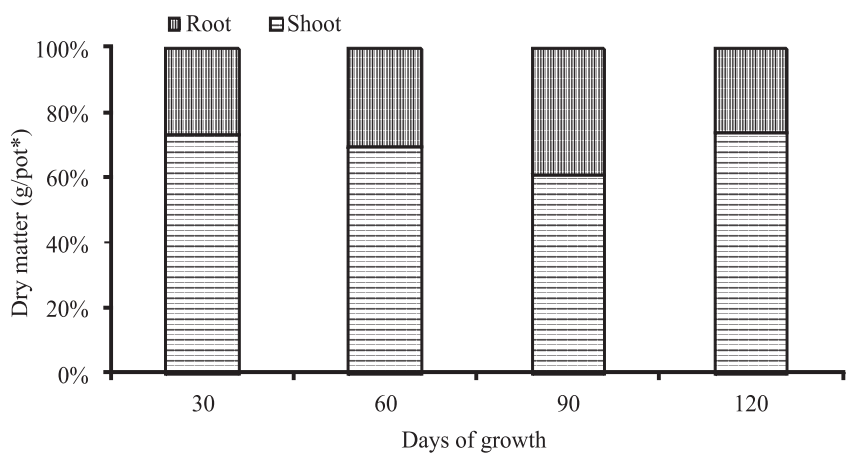

Figure 3 - Dry matter allocation of tough lovegrass considering the days of growth on the average of two populations. *Average of three plants. 
tillers with elongated internodes. Cuttings at $5 \mathrm{~cm}$ strongly reduced the live stubble and the shoot above this residue in relation to $10 \mathrm{~cm}$, but the root production was not affected. In general, severe defoliations reduce the root system, contrary to what was verified in tough lovegrass. In Bromus auleticus Nees, a winter grass from the natural pastures of the south of Brasil, a decline in root dry matter was observed under cutting at $5 \mathrm{~cm}$ in relation to $10 \mathrm{~cm}$ cutting height (Scheffer-Basso et al., 2002).

As observed in Experiment I, the plants showed high allocation to roots (Figure 4), which suggests that it may be a characteristic of the species. In the plants whose first cutting was carried out in the flowering stage, the root dry matter reached $47 \%$, compared with $40 \%$ observed in plants whose first cutting occurred in the vegetative stage. The highest amount of dead stubble on the former was due to greater number of tillers that were cut, which had its internodes elongated and, consequently, the growing point above the cutting height (Table 2). This fact showed the flowering synchrony in tillers of the same age, which resulted in the great dead stubble accumulation (Figure 4). In the plants cutting from the vegetative stage, as most of the tillers (59\%) were below the cutting height, there was a smaller amount of this fraction in the final harvest.

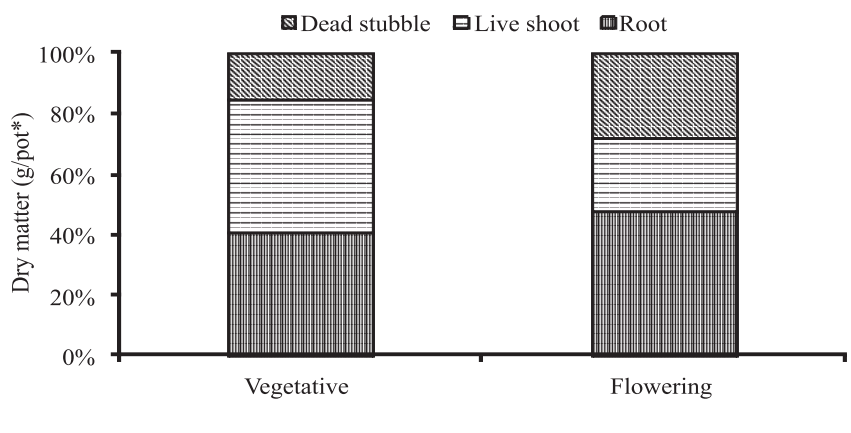

Phenological stage at the first cutting

Figure 4 - Dry matter allocation of tough lovegrass after three monthly cuttings considering the phenological stage at the first cutting.

Table 1 - Effect of phenological stage at the first cutting and cutting height on morphophysiological attributes of tough lovegrass after three monthly cuttings

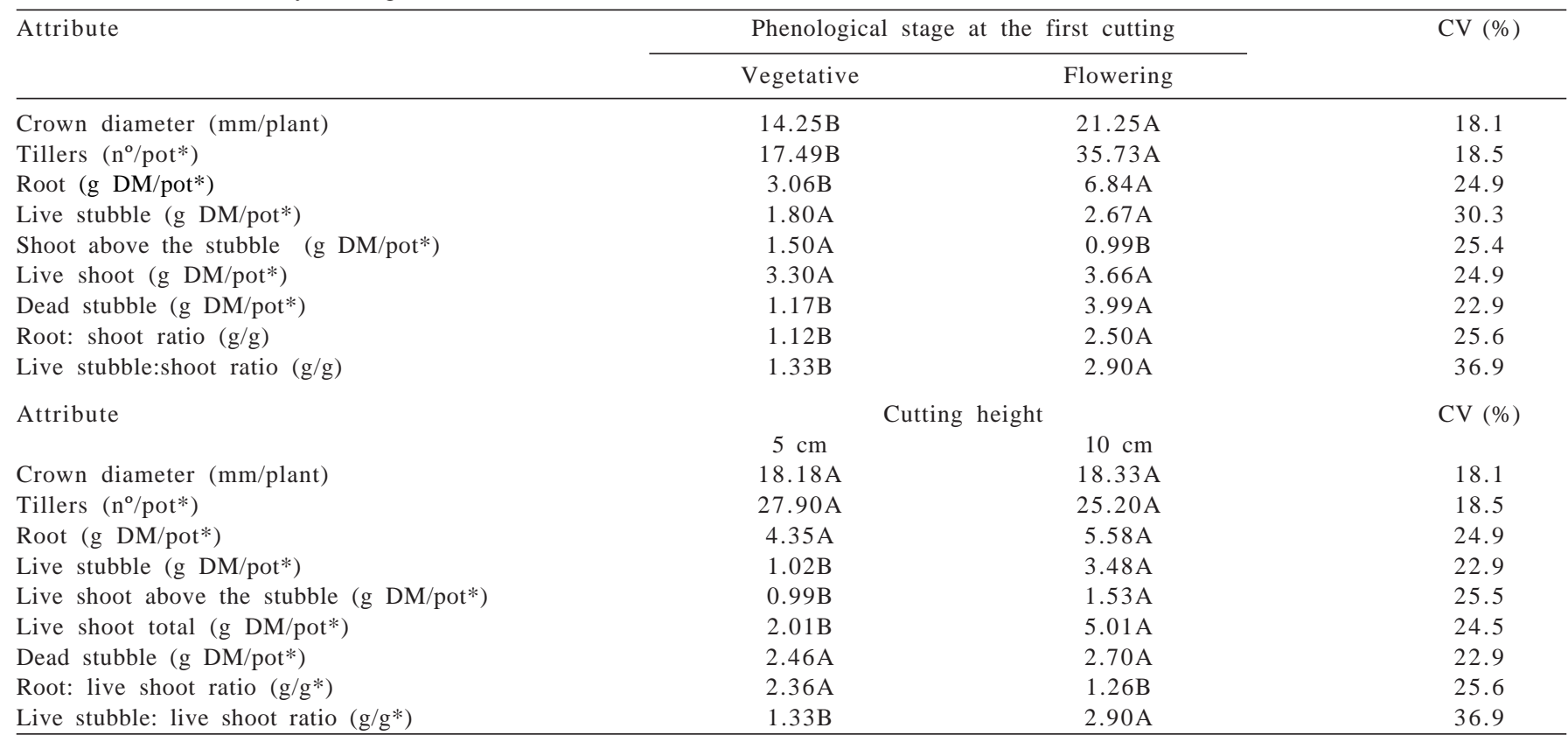

Means followed by the same letter in the row do not differ ( $\mathrm{P}>0.05)$ by Tukey test.

*Average of three plants; CV - coefficient of variation; DM - dry matter.

Table 2 - Morphophysiological attributes of tough lovegrass in the first cutting performed at vegetative and flowering stages

\begin{tabular}{lcc}
\hline Attribute & \multicolumn{2}{c}{ Phenological stage at the first cutting } \\
\cline { 2 - 3 } & Vegetative & Flowering \\
\hline Total tillers $\left(\mathrm{n}^{\circ} /\right.$ pot*) $\left.^{*}\right)$ & $19.80 \mathrm{~A}$ & $25.50 \mathrm{~A}$ \\
Tillers above the cut height $\left(\mathrm{n}^{\circ} /\right.$ pot*) $^{*}$ & $8.40 \mathrm{~B}$ & $25.50 \mathrm{~A}$ \\
Tillers below the cut height $\left(\mathrm{n}^{\circ}\right.$ pot*) $^{*}$ & $5.70 \mathrm{~A}$ & $0.00 \mathrm{~B}$ \\
Shoot above the stubble $\left(\mathrm{g} \mathrm{DM} /\right.$ pot $\left.^{*}\right)$ & $1.44 \mathrm{~B}$ & $2.01 \mathrm{~A}$ \\
\hline
\end{tabular}

Means followed by the same letter in the row do not differ ( $\mathrm{P}>0.05)$ by Tukey test.

*Average of three plants; CV - coefficient of variation; DM - dry matter. 
In the plants whose first cutting occurred in the beginning of flowering, there was significant increase of total tillers between the first and the last cutting, contrary to what happened with plants cutting in the vegetative stage (Figure 5). The opposite was verified for the tillers above cutting height. In spite of the stabilization in the removed tillers by cuttings, there was decline in the yield of plants cutting at the first time in the flowering stage (Figure 6 ). The reduction in DM production varied from $58 \%$ (vegetative) to $68 \%$ (flowering) considering the phenological stage at the first cutting. This behavior suggests that the precocious mechanical control of tough lovegrass, when the plants are young, can minimize the plant size and reduce root and shoot yield. For the areas infested by tough lovegrass, Alfaya et al. (2002) suggested the cutting before the seed set as an alternative to slowly reduce the soil seed bank. The control techniques must deplete the seed bank, avoid the reposition of new propagules and eliminate the new plants (Reis \& Coelho, 2000), as well as with crop rotation and herbicide application (Moraes et al., 2008).
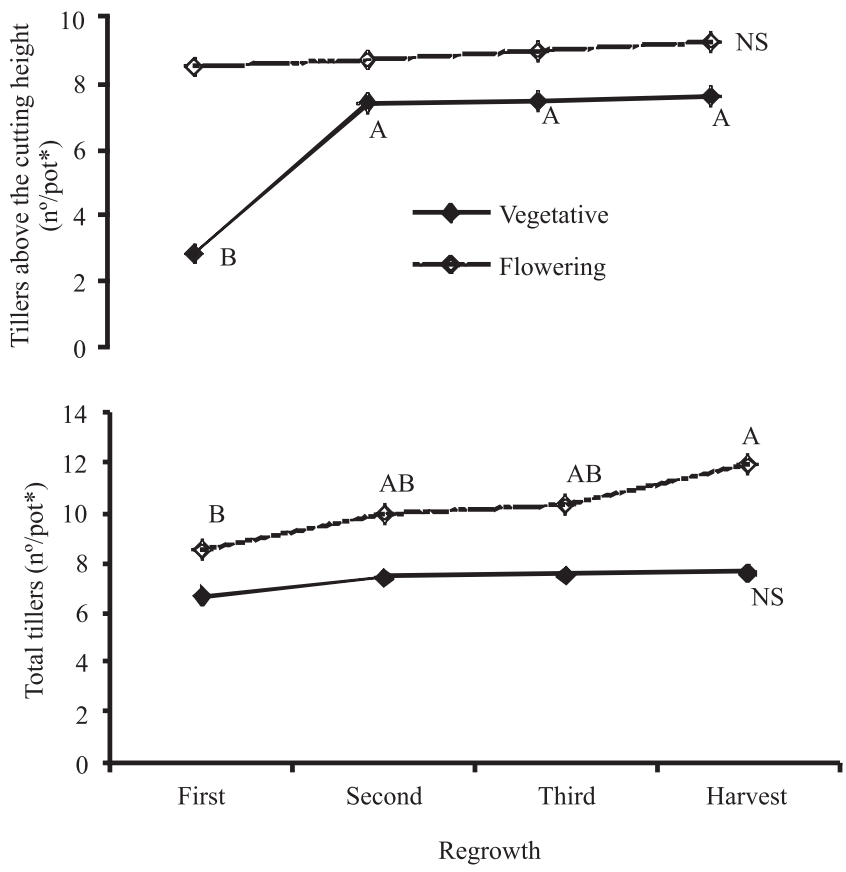

Figure 5 - Number of total tillers and tillers above the cutting height in the regrowth of the tough lovegrass, considering the phenological stages at the first cutting. Capital letters show similarity between values in each phenological stage by Tukey test $(\mathrm{P}>0.05)$. NS - non significant; DM - dry matter. *Average of three plants. Coefficient of variation (\%): tillers above the cutting height $=12.6$; total tillers $=17.6$.

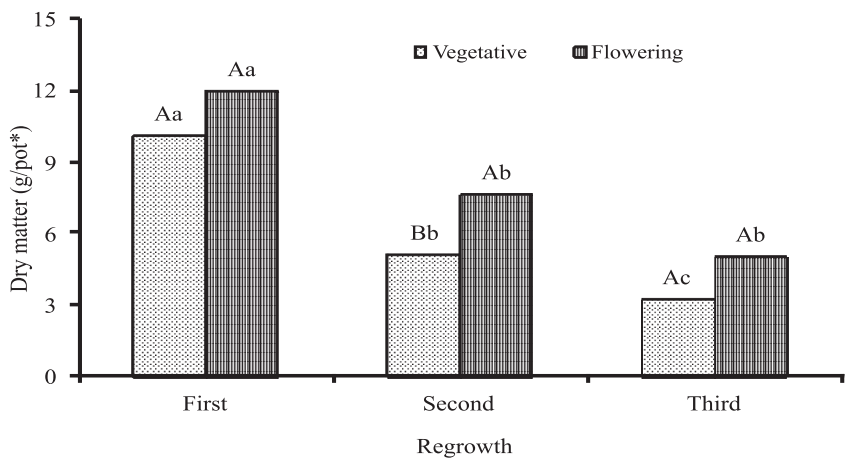

Figure 6 - Effect of the phenological stage at the first cutting in dry matter production of regrowth of tough lovegrass. Same lowercase letters comparing regrowth means and capital letters comparing stages show similarity $(\mathrm{P}>0.05)$ by Tukey test. *Average of three plants. Coefficient of variation $(\%)=18.6$.

Considering that pastures invaded by tough lovegrass have many species of high forage value, like Bromus spp., Briza spp. and Paspalum spp., drastic mowing also might reduce the vigor of these grasses. The time and intensity of the mechanical control need to be strategic in order to maximize the reduction of tough lovegrass, with minimum damage to desirable plants. However, considering the importance of competitive interaction in determining the outcome of defoliation (Archer \& Detling, 1984), experiments on field are necessary to extrapolate the results of this study.

\section{Conclusions}

Tough lovegrass shows basal architecture, basal bud renovation, leaves densely compressed in the tiller base, high belowground allocation and elongation of internodes only in the reproductive stage. Mechanical control is an alternative method to minimize its growth, especially if carried out early in the growing season and at low cutting height.

\section{References}

ABICHEQUER, A.D.; BICCA, A.M.O.; MEDEIROS, C.M.O. et al. Crescimento e distribuição de raízes de capim-annoni-2 e do campo nativo: vantagem competitiva do campim-annoni-2? Pesquisa Agropecuária Gaúcha, v.15, n.1, p.7-12, 2009.

ALFAYA, H.; SUÑÉ, L.N.P; SIQUEIRA, C.M.G. et al. Efeito da amonização com uréia sobre os parâmetros de qualidade do feno do capim-annoni-2 (Eragrostis plana Nees). Revista Brasileira de Zootecnia, v.31, n.2, p.842-851, 2002.

ARCHER, S.; DETLING, J.K. The effects of defoliation and completion on regrowth of tillers of two North America mixed-grass prairie graminoids. Oikos, v.43, n.3, p.351-357, 1984.

BARÉA, K.; SCHEFFER-BASSO, S.M.; FAVERO, D. Desenvolvimento morfológico de Paspalum paniculatum L. (Poaceae). Revista Biotemas, v.19, n.4, p.33-39, 2006. 
BRINK, M. Eragrostis plana Nees. In: BRINK, M.; BELAY, G. (Eds.). Plant resources of Tropical Africa. Wageningen, Netherlands. 2006. Available at: <http://database.prota.org>. Accessed on: Oct. 10, 2010.

COELHO, R.W. Substâncias fitotóxicas presentes no capim-annoni2. Pesquisa Agropecuária Brasileira, v.21, n.3, p.255-263, 1986.

COPE, T. A synopsis of Eragrostis Wolf (Poaceae) in the Flora Zambesiaca Area. Kew Bulletin, v.53, n.1, p.129-164, 1998.

CRAINE, J.M. The role of nitrogen in grasslands: from ecophysiology to ecosystem and competion to herbivory. In: INTERNATIONAL RANGELANDS CONGRESS, 7., 2003, Durban. Proceedings... Durban, 2003. p.6-13.

DESCOINGS, N. Les types morphologiques et biomorphologiques des graminoides dans les formations herbeuses tropicales. Naturalia Monspeliensia, v.25, p.23-25, 1975.

FAVARETTO, A.; SCHEFFER-BASSO, S.M.; FELINI, V. et al. Growth of white clover seedlings treated with aqueous extracts of leaf and root of tough lovegrass. Revista Brasileira de Zootecnia, v.40, n.6, p.1168-1172, 2011.

FERREIRA, D.F. Sistema de análises de variâncias para dados balanceados - SISVAR 4.1. Lavras: Editora UFLA, 2000. 141p.

KISSMANN, K.G.; GROTH, D. Plantas infestantes e nocivas. 2.ed. São Paulo: BASF, 1997. 825p.

MEDEIROS, R.B.; FOCHT, T. Invasão, prevenção, controle e utilização do capim-annoni-2 (Eragrostis plana Nees) no Rio Grande do Sul, Brasil. Revista Agropecuária Gaúcha, v.13, n.1-2, p.1-28, 2007.
MORAES, P.V.D.; REIS, J.C.L.; MONKS, P.L. et al. Margem bruta de sucessão de culturas usadas para controle do capim-annoni-2 (Eragrostis plana Nees). Revista Agropecuária Gaúcha, v.14, n.2, p.135-141, 2008.

NASCIMENTO, A.; HALL, G.A.B. Estudos comparativos de capim annoni-2 (Eragrostis plana) e pastagem nativa de várzea da região de Santa Maria, Rio Grande do Sul. 1. Características químico-bromatológicas. Pesquisa Agropecuária Brasileira, v.13, n.2, p.7-14, 1978.

OLIVEIRA, M.A.; PEREIRA, O.G.; HUAMAN, C.A.M. et al. Características morfogênicas e estruturais de capim bermuda “Tifton 85" (Cynodon spp.) em diferentes idades de rebrota. Revista Brasileira de Zootecnia, v.29, n.6, p.1939-1948, 2000.

REIS, J.C.L.; COELHO, R.W. Controle do capim-annoni-2 em campos naturais e pastagens. Pelotas: EMBRAPA-CPACT, 2000. 21p. (Circular Técnica, 22).

SCHEFFER-BASSO, S.M.; SOARES, G.C.; DALL'AGNOL, M. Efeito da frequência e altura de corte em dois genótipos de Bromus auleticus Trin. Ex Nees. Revista Brasileira de Agrociência, v.8, n.3, p.191-194, 2002.

SCHEFFER-BASSO, S.M.; GALLO, M.M. Aspectos morfofisiológicos e bromatológicos de Paspalum plicatulum. Revista Brasileira de Zootecnia, v.37, n.10, p.1758-1762, 2008.

WELKER, C.A.D; LONGHI-WAGNER, H.M. A família Poaceae no Morro Santana, Rio Grande do Sul, Brasil. Revista Brasileira de Biociências, v.5, n.4, p.53-92, 2007. 